\title{
Compensation Management and Employee's Work Commitment in the Kwara State Internal Revenue Service, Ilorin, Nigeria
}

\author{
Emmanuel Olaniyi, Dunmade ${ }^{1}$ \\ dunmade.eo@unilorin.edu.ng \\ Department of Industrial Relations and Personnel Management, \\ University of Ilorin, Ilorin, Nigeria \\ Emmanuel Adewale, Adeyemi ${ }^{2}$ \\ Department of Business Administration, University of Ilorin, Ilorin, Nigeria \\ Ismaila Bolarinwa, Kadiri ${ }^{3}$ \\ bolakadiri@unilorin.edu.ng \\ Department of Industrial Relations and Personnel Management, \\ University of Ilorin, Ilorin, Nigeria \\ Modupe Olayinka, Ajayi ${ }^{4}$ \\ Department of Project Management, Federal University of Technology, Akure
}

\begin{abstract}
The study examines the effect of compensation management on the employee's work commitment in the Kwara State Internal Revenue Service (KW-IRS), Ilorin, Nigeria. Stratified random sampling technique was utilized for the study with the administration of structured questionnaire to the respondents so as to elicit the required information. The data generated was analyzed with regression analysis with aid of SPSS, (V. 22.0). Findings showed that compensation management is a positive and significant predictor of employee's work commitment in the Kwara State Internal Revenue Service. The study concluded that organizations that effectively and efficiently manage its compensation policy, in respect to employee's commitment, will outperforms those organizations that do not. Thus, the study recommends the organization should be more innovative and effective in the management of compensation policies, so as to focus more on the adequate welfare for the employees and as well treating them as the most precious assets of the establishment.
\end{abstract}

Keywords: Commitment; Compensation; Employees; Management; and Motivation

Jel Classification Codes: M 520, M 500; and M 590.

\section{INTRODUCTION}

In the world of work, human capital is the pivotal of organizational effectiveness and the most treasured asset that is available to the workplace and its people. This 
necessitates effective management of workforces as the most valuable assets for job commitment and increased performance, which could be facilitated through effective compensation management to the deserving workforces. However, compensation management is a segment of administration that focuses on planning and directing of payments that employees receive for the work performed. It signifies both intrinsic and extrinsic rewards that workers are entitled to for performance of their jobs (Daniel, 2019). This is a key human resource practice that influences decision of probable worker to be part of the organization's workforce and to determine employer-employee relationship after employee joins the establishment (Ira, 2010).

Therefore, the relationship that exists between employers coupled with shareholders and respective employees is undoubtedly expected to be mutually reciprocal. This is due to the fact that employers look up to the employees to offer their best in the areas of work performance, learning and selfdevelopment, adherence to workplace's rules and regulations so as to ensure higher productivity. Conversely, employees equally anticipate that employers would be innovative, having initiative ideas for solving workplace's problems and putting up an ideal compensation plan for services rendered by them to the organization. Additionally, employees require the employer to make available the necessary tools and equipment needed to work with and to obtain fair compensation for the work done and services offered. Therefore, at the minimum, employees expect the kind of compensation that will motivate them to give their best and as well addresses their basic needs.

In an attempt to identify and retain competent and highly knowledgeable employees in today's dynamic business environments, organizations are required to consider a variety of appropriate means to reward the employees so as to get the desired results from them. This is due to the fact that the degree to which these workers are satisfied with their jobs and also their readiness to be loyal to the organization are functions of the compensation packages. Thus, it has become important for organizations to effectively manage its employees so as to ensure progressiveness in the midst of fierce competition and in realizing the organizational goals (Saharuddin, Abdul, Baharuddin, \& Budiandriani, 2020).

On similar note, employees' work commitment is similarly a key factor that organizations must constantly strive to attain and maintain. Employees' work commitment is a reflection of the engrossment and mental attachment that an individual employee possesses towards a workplace and his allocated duties. Employees' work commitment is imperative to organization's 
progressive productivity because it has a tendency to influence whether an employee leaves to pursue another job elsewhere or remains in the organization (Daniel, 2019). Employees' work commitment is a psychological bond characterized by individuals' feeling of attachment, responsibility, and loyalty to a known organization (Dunmade, Kadiri, Aun, Bello \& Yahaya, 2019). It is a force that causes an employee to take to a course of action that is pertinent to a specific goal of the organization (Meyer \& Herscovith, 2001). Generally, employees' work commitment describes how devoted employees are to their duties and the feelings that they have towards the various aspects of their jobs. Work commitment has turned a very vital feature in every organization due to its importance to the behavior exhibited by employees in the workplace. Thus, human resources managers tend to adopt reward programmes capable of enhancing employees' job satisfaction, commitment and in turn increase organizational performance or productivity.

\section{Compensation policy is} nonetheless a central element of workplace's reward systems and corporate strategy which when meritoriously adopted impacts greatly on the workers' level of commitment (Armstrong, 2007). However, a number of organizations, not realizing the significant benefits of fair compensation programmes, were known for lack of decent compensation administration programmes, resulting in a situation in which their workforces were poorly paid; delay in some employees' promotions and employees not been able to have their entitlements paid promptly. Consequently, the organization suffers in terms of poor productivity as a consequential result of employees' lax attitude to work, absenteeism, and eventually customers' dissatisfaction.

In Nigeria, despite the growing interest of organizations in providing successful incentive systems that can inspire workers to work harder and increase their job commitment. However, most workers seem disappointed with their compensation packages, thus making the pace at which employees' turnover in the government's establishments a matter of concern. This points out that the measures taken by management and stakeholders are yet to resolve the problem of fair compensation in relation to employees' commitment (Osibanjo, Adeniji, Falola, \& Heirsmac, 2014).

Furthermore, high employee turnover is a clear trend in most governmental organizations and institutions in Nigeria, in which Kwara State Internal Revenue Service (KWIRS) is not an exception. Kwara State Internal Revenue Service (KW - IRS) is an agency of the Kwara State Government with the corporate headquarters located at 9, Ahmadu Bello way, G.R.A, Ilorin, Kwara State, Nigeria with area offices sited in all 
the 16 local governments of the state. It was formed with the sole responsibility of effectively and efficiently administrating taxes and related matters on behalf of the State Government. This organization is however confronted with the dilemma of employee turnover due to its inability to attract and retain highly skilled workers, because they find it difficult to match the salaries offered by their competitors in private sectors. Besides, a closer look at the operation of the organization point out that it was more concerned only on actualization of its goals while neglecting the compensationsatisfaction of its employees (Khudhair, Rahman \& Adnan, 2020), which is detrimental to its healthiness.

Nevertheless, this study was carried out with a particular reference to Kwara State Internal Revenue Service (KW - IRS), Ilorin, Nigeria as a case study. This was due to the fact that the organization's recently undergone challenges such as employees' reduced work commitment, absenteeism, and high turnover resulting from the management's failure to recognize the importance of workers indispensability to organizations' efforts towards goals actualization. These were coupled with poor incentive payments to these workforces. It is therefore considered expedient for the management of the establishment to come to realization of the fact that the problems might tend to persist as long as employees perceive imbalance in their input- output ratio with reference to other employees elsewhere, particularly in the private sector. Thus, the organization should be able to offer the compensation plan that ensure enviable work conditions adequate enough to motivate employees towards optimum work commitment (Muhammad, Andi, Muhtar, \& Hanifah, 2018). This would enable workers to offer their best in terms of performance since it is the responsibility of any workplace to compensate its workforces for their performances (Prayoga \& Achmad, 2017).

Compensation management seems to have attracted attention recently in today's world of work, and particularly in Nigeria. Previous studies utilized factors such as productivity, financial metric performance, job satisfaction, and so on for assessment of the impact of employees' compensation. However, most of these studies differ in the case studies used, and time frame in which they were undertaken. Hence, this study attempted to provide an effective mechanism for reformulation of policies capable of remedying the trend of employees' dissatisfaction, non- commitment and disloyalty to the workplace. This becomes essential as it is obvious that no empirical study has been conducted on compensation management and employee's work commitment in KW-IRS, Ilorin, Nigeria. It is thus this gap that this study seeks to bridge. 
The specific objective is to examine the effect of compensation management on employees' job commitment. The research question raised to guide the study is: To what extent is compensation management has significant effect on employee work commitment? Thus, in a bid to achieve the stated research objective, a hypothesis was formulated in null form: $\mathrm{Ho}_{1}$ : Compensation management has no significant effect on employee' commitment among the staff of KWIRS.

\section{LITERATURE REVIEW}

\section{Concept of Compensation Management}

Compensation signifies all kinds of tangible services and benefits together with financial returns that workers obtain as part of an engagement relationship. It is a wide range of financial and non-financial rewards offered to employees in return for their rendered services to the organization. This is paid in the form of wages, salaries and employee benefits such as paid vacations, maternity leave, insurance, retirement benefits, free traveling facility, etc. The term 'wage' implies remuneration to workers doing manual or physical work. Thus, wages are provided to compensate the unskilled workers for their services rendered to the organization, while wages may be based on hourly, daily, weekly or even monthly bases. In line with DeNisi and Griffin (2001), compensation is a reward system that an establishment make available to its workforce in return for their readiness to perform various jobs and tasks within the organizations.

However, compensation management is an overall policy that is being put in place to assist the workplace to make best use of its proceeds on the existing talents. It refers to a systematic method of giving monetary value to workers in exchange for the performed works (Dunmade et al, 2019). This is the structure, policy, and procedure that enable places of work to pay fairly their workforces based on their level of performance (Chhy, 2019). That is, rewarding the right man to the fullest for key reasons. As stated by Barr, Arif and Shoaib (2013), compensation management implies the scheme through which rewards are allocated to the employees. Anthony and Govindarajan (2001) argue that appropriate and adequate rewards are required to be given to the workforces for them to have a sense of importance and expectations on bargaining their services and input to the organization.

\section{Concept of Employee's Work Commitment}

Work commitment can be referred to as the level at which an employee is identified with an organization and works towards its success. Commitment as a term has been previously described severally by different authors. Meyer; Becker and Van Dick (2006) consider commitment as a force that binds a workforce to a target such as an organization and 
subsequently to a course of action of relevance to that target. Likewise, Dunmade et al (2019) describe the concept as the employees' acceptance level of the workplace's goals and disposition to work towards these goals. Pare (2007) is of the opinion that employee commitment is a phenomenon that is linked to behaviours of great involvement, decreased intents of quitting the workplace, doing more to perform an assignment, possessing desire to assist in ensuring the elevation of colleagues at work and corporate citizenship. According to Ira (2010), work commitment is seen as inner psychosomatic force that organizes an individual for the exercise capable of guaranteeing the achievement of the definite assignment as indicated, to be loyal to the place of work, and to equally say good things about such an establishment.

The employees who possess strong organizational commitment have emotionally attachment to the workplace and are also expected to have robust aspiration to contribute meaningfully to the organization's success, thus leading to healthier competitiveness, increased risk taking, highly innovativeness, better accountability, low wastage, and the desire to enhance the overall organizational performance.

Therefore, workforce's commitment can be enhanced by providing the employees with the required skills for decision making, problem solving, shared leadership, and general understanding of the enterprise (Kandula, 2004).

Approaches to Employees'
Commitment

According to Suliman and Isles (2000), the following are the approaches to employees' commitment at work:

\section{Affective commitment:}

This is known as attitudinal commitment (Torrington, Hall, \& Taylor, 2005). It shows the extent to which the workers like their membership of an organization and identify themselves with it. This is often influenced by the persons' expectations about the workplace.

\section{Continuance commitment:}

Continuance commitment refers a calculative commitment (Hansen, Sandvik \& Selnes, 2003). It is the cognizance of the impracticality of deciding on a different social identity due to the great consequences involved in making the switch.

Normative commitment:

This denotes the workers' feeling of duty to be loyal to the organization and focusing on the legal things to do (Culpepper, Gamble \& Blubaugh 2004). Specifically, the scope of this study is tailored towards all the approaches as they all influenced employees' work commitment. 


\section{Relating Compensation with Employees' Work Commitment}

Employee's commitment is the extent to which a worker identified with a particular organization and dedicated to its mission and goals. Thus, it can be argued that this is a function of the margin between the reward expectations of an employee and the duties that he performs in the organization. The outcome may either leads to job satisfaction or dissatisfaction. In an event where he is inadequately compensated for his contributions to the organization, job dissatisfaction arises. This can then leads to decline in his work commitment and upsurge in the rate of the optional cessation of the job. Consequently, this makes it impossible for the organization to be at its best because its workforces are not committed to its goals and objectives (Dixit \& Bhati, 2012).

Additionally, the extent to which an employee is committed to work schedule differs and is dependent on factors such as job environment, work schedules, and offered compensation packages (Osibanjo et al, 2012). In other word, worker's commitment is a function of job contentment from the workplace's reward system, implying that an employee can only be committed into delivering his services when he is adequately compensated.

\section{Theoretical Framework}

Undoubtedly, there exist a number of theories to explicate compensation management and employee's work commitment. However, expectancy theory provides fundamental theoretical background for this study due to the fact that it provides the basis of explaining the relationship between compensation management and employee's work commitment. Expectancy theory is very important in the context of this study because it is instrumental in drawing up performance-based employee's welfare schemes. Expectancy theory illuminates on the rationale behind the employee's feeling of confidence that he can and will grow so as to reach the peak of his career in the same organization, and therefore be loyal to it or trying to find development elsewhere by withdrawing his service from such an organization.

\section{Expectancy Theory}

Expectancy theory is recognized as a theory that detailed on the employee's mental process in interpreting organizational compensation occasioning behaviours of commitment, inspiration and enhanced efforts. The theory was developed by Vroom (1964) and basically suggests that compensation policy is not only futuristic in nature, but it is as well influences expectancy attitude and behaviour of employee towards job commitment in an organization. Vroom submits that workers' behavior towards duty is associated with the belief that their effort is for definite accomplishment of specific goals and objectives of the 
organization, hence, they expected to be compensated for the effort made in ensuring the accomplishment of the goals and objectives. The theory is centered on three main expectancies; effort-performance expectancy (E-P), performance - outcome expectancy $(P-O)$ and Valence $(V)$. E-P refers to the thought that a person holds in the workplace that both meaningful and desired relationship exist between made effort and performance with improved effort resulting in performance. P-E is the individual's calculation that high performance will produce positive outcomes in term of rewards. Then $\mathrm{V}$ denotes the value expectation of the employee towards the compensation. Hence, the individual employee has no choice other than to be hard-working in his duty where his efforts will yield greater performance.

Vroom maintained that an employee will make continuous effort only when the outcomes of his reward is connected to effort as well as performance and when these are considered to be fair or are of great value. Therefore, employee is appropriately guided in making predictions and expectations about the works when compensation policy of the organization is well articulated and clearly communicated. This, therefore makes the behavior of the employee and effort towards his job to be influenced pleasantly when he construes the expected valence in the predicted rewards.

\section{Empirical Review}

Larbi (2014) examined the impact of compensation management on the performance of employee with a focus on a Hospital in Ghana. The structured questionnaire was therefore adopted for data collection. The findings of the study showed that lack of employees' full awareness of the existing compensation plans despite their availability due to too poor communication by the hospital's management on the policy in addition to the non- involvement of the low level or cadre staff of the hospital in the creation and application of the strategies were the main challenges associated with the compensation management in the studies medical organization.

In the study of Koitalek (2016) which aimed at examining the impact of compensation policy on employee's commitment at Teachers Service Commission (TSC), Kenya. Primary data was collected through the use of questionnaire. The collected data were analyzed using descriptive statistics and regression analysis. The findings revealed that compensation policies of TSC significantly influence employees' commitment in the commission such that it had often led to the enhancement of the staff's performance, increased the employees' trust in the management, and as well resulted in the robust relationship between the organization's management and the workers. 


\section{METHODOLOGY}

The study adopts descriptive survey research design as this is suitable to capture the details of the relationship of various variables. The population of the study comprises of all the employees of Kwara State Internal Revenue Service (KW-IRS), Ilorin, and the 16 Local Government Areas. The study employed a hypothetical sample due to the inability to establish the total number of the workers in the studied organization. This was in accordance with the view of Attewell and Rule (1991), and Bradford and Cullen (2012) that hypothetical sample is applicable for use where population of the study could not be well-known or established. Thus, a total number of two hundred and fifty staff members of KW-IRS, at the corporate headquarters and other selected local government offices, specifically from non-managerial positions of the organization, were randomly selected as sample. This set of employees was selected due to the fact that they are more directly affected by the organization's compensation management policy. The selection of 250 staff was in agreement with Hill, Brierley and McDougall (2003)'s idea that a sample size of one hundred and above is sufficient enough to make acceptable research findings.
The primary data was collected through structured questionnaire. The questionnaire was further divided into two sections. The first section captured the respondents' demographic information, while the second part focused on items related to compensation management and employees' job commitment. Likert rating scale of five points which range from strongly agreed (5 points) to strongly disagree (1) was constructed to enable the respondents give their opinions to items in the questionnaire.

Cronbach's Alpha was used to ascertain the reliability of the instrument. The satisfactory value is expected to exceed 0.7 for the scale to be reliable (Pallant, 2007). Thus, as shown in table 1 below, the Cronbach's Alpha values for all the variables depict a high reliability and the overall measure of the scale is highly reliable since the Cronbach's Alpha value exceeds 0.7 (0.829), showing high internal consistency among all the items included in the scale. The study used face and content validity for instrument validation. The structured questionnaire that was drafted was given to senior lecturers in the Department of Business Administration, University of Ilorin for validation. Their suggestions and corrections were integrated into the final draft of the instrument. 
Table 1 Cronbach's Alpha

\begin{tabular}{llll}
\hline Variables & $\begin{array}{l}\text { Number } \\
\text { Items }\end{array}$ & of & $\begin{array}{l}\text { Cronbach's } \\
\text { Value }\end{array}$ \\
\hline Overall & 10 & 0.829 \\
Employee Commitment & 5 & 0.767 \\
Compensation & 5 & 0.789 \\
Management & & & \\
\hline
\end{tabular}

Source, Field Study, 2020

Regression analysis, with the aid of SPSS (version 22.0), was used as the statistical tool for analysis and to test the hypotheses formulated.

Model Specifications

$\mathrm{EmCom}=\mathrm{f}(\mathrm{ComMgt})$

$\therefore$ EmCom $=\beta_{0}+\beta_{1}$ ComMgt $+\varepsilon$

Where:

EmCom $=$ Employee Commitment (Dependent variable)

$\beta_{0}=$ Intercsept of the model.

$B_{1}=$ Estimate of the parameter of the independent variable in the model of the slope. $\varepsilon=$ Error term.

ComMgt $=$ Compensation Management (Independent variable)

\section{RESULTS AND DISCUSSION}

The responses to the questionnaires administered posit that out of the 250 copies of questionnaire administered, 218 copies representing 87.2\% were returned and considered appropriate for the study. This shows that a larger proportion of the respondents positively responded to the questionnaire, making it relevant for the study.

Table 2: Analysis of Response to the Administered Questionnaire

\begin{tabular}{lcc}
\hline \multicolumn{1}{c}{ Description } & Frequency & Percentage \\
\hline Administered & 250 & 100 \\
Returned & 218 & 87.2 \\
Not Returned & 32 & 12.8 \\
\hline
\end{tabular}

Source: Field Survey, 2020

Descriptive analysis of the as shown in Table 3, posits that demographic data of the respondents, greater part $(57.8 \%)$ of the staff of $\mathrm{KW}$ 


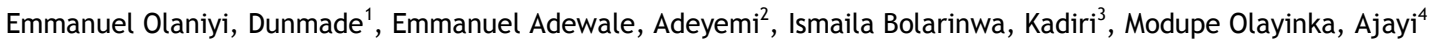
Compensation Management and Employee's Work Commitment in the Kwara State Internal Revenue Service, Ilorin, Nigeria

- IRS were females of which $60.1 \%$ of them were between 31-40 years. Similarly, $72.0 \%$ of the staff were senior staff in which $69.8 \%$ were HND/First Degree holders. In addition, $57.8 \%$ of the workers had been working for between 2-4 years. More staff from MDAs department than other department participated in the study as their percentage was $41.8 \%$, while the least was sampled from corporate directorate and informal sectors with $4.1 \%$ each. This indicates that larger proportions of the respondents was more than averagely educated and are in best position to comprehend the concepts as contain in the instrument.

Table 3: Socio-Demographic Data of the Respondents

\begin{tabular}{|c|c|c|c|}
\hline Variable & Level & Frequency (f) & Percentage (\%) \\
\hline \multirow{3}{*}{ Gender } & Male & 92 & 42.2 \\
\hline & Female & 126 & 57.8 \\
\hline & Total & 218 & 100.0 \\
\hline \multirow{3}{*}{ Age } & 21-30years & 47 & 21.6 \\
\hline & 31-40years & 131 & 60.1 \\
\hline & 41-50years & 40 & 18.3 \\
\hline \multirow{4}{*}{ Job Designation } & Total & 218 & 100.0 \\
\hline & Senior Staff & 61 & 28.0 \\
\hline & Junior Staff & 157 & 72.0 \\
\hline & Total & 218 & 100.0 \\
\hline Level of Education & OND & 9 & 4.1 \\
\hline \multirow{7}{*}{ Length of Service } & HND/Degree & 152 & 69.8 \\
\hline & Masters & 57 & 26.1 \\
\hline & Total & 218 & 100.0 \\
\hline & 0-1year & 44 & 20.2 \\
\hline & 2-4years & 126 & 57.8 \\
\hline & 4-5years & 48 & 22.0 \\
\hline & Total & 218 & 100.0 \\
\hline \multirow{10}{*}{$\begin{array}{l}\text { Directorates } \\
\text { (Department) } \\
\text { Distribution }\end{array}$} & Legal Enforcement & 14 & 6.4 \\
\hline & Corporate Directorate & 9 & 4.1 \\
\hline & Informal Sector & 9 & 4.1 \\
\hline & MDAs & 91 & 41.8 \\
\hline & Property tax & 17 & 7.8 \\
\hline & Special Duty & 13 & 6.0 \\
\hline & Other Revenue & 22 & 10.1 \\
\hline & Tax assessment and Audit & 26 & 11.9 \\
\hline & Account Finance and Reconciliation & 17 & 7.8 \\
\hline & Total & 218 & 100.0 \\
\hline
\end{tabular}

Source: Field Survey, 2020 
INDONESIAN JOURNAL OF BUSINESS AND ECONOMICS

Vol. 3 Issue 2, Desember 2020
Test of Hypothesis

$H_{01}$ : Compensation management has no significant effect on employee' commitment among the staff of $\mathrm{KW}$-IRS
The regression analysis results to determine whether or not compensation management (ComMgt) has significant effect on employee commitment (EmCom) were presented in table 4 to 6

Table 4

Model Summary

\begin{tabular}{lllll}
\hline Model & $\mathrm{R}$ & R Square & Adjusted R-Square & $\begin{array}{l}\text { Std. Error of the } \\
\text { Estimate }\end{array}$ \\
\hline 1 & $.679^{\mathrm{a}}$ & .461 & .458 & .697 \\
\hline
\end{tabular}

a. Predictors: (Constant), ComMgt

Source: Authors' Computation, 2020

The model summary shown in table 4 posits that compensation management (ComMgt) has significant effect on employee commitment (EmCom). The correlation coefficient (R) value of $0.679(67.9 \%)$ posits a significant and strong relationship between employee commitment (the dependent variable) up to 0.679 $(67.9 \%)$. The R-square value of 0.461 (46.1\%) indicates that the independent variable (compensation management) has a combine effect of 0.461 (46.1\%) on the dependent variable (employee commitment). The adjusted $\mathrm{R}^{2}$ helps to establish the actual effect of the independent variable on the dependent variable. The adjusted $\mathrm{R}^{2}$ Table 5

(EmCom) and compensation management (ComMgt). This shows that the cumulative effect of compensation management (the independent variable) is able to explain variability changes in employee commitment

value of $0.458(45.8 \%)$ indicates that compensation management (ComMgt) actually contribute to variation in the level of employee commitment (EmCom). This is good enough in determining the goodness of fit for the model. The regression model proved to be very useful for making predictions since the value of $R^{2}$ is close to 1.

\begin{tabular}{lllclll}
\hline Model & & Sum & of $\mathrm{df}$ & Mean Square & $\mathrm{F}$ & Sig. \\
& & Squares & & & & \\
\hline \multirow{3}{*}{1} & Regression & 89.717 & 1 & 89.717 & 184.693 & $.000^{\mathrm{b}}$ \\
& Residual & 104.925 & 216 & .486 & & \\
& Total & 194.642 & 217 & & & \\
\hline
\end{tabular}

a. Dependent Variable: EmCom

b. Predictors: (Constant), ComMgt

Source: Authors' Computation, 2020 


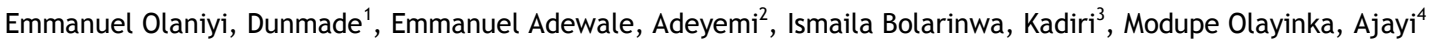
Compensation Management and Employee's Work Commitment in the Kwara State Internal Revenue Service, Ilorin, Nigeria

Table 5 revealed that the calculated P-value is 0.000 (positive) and is less than the tabulated P-value of 0.05 at 95\% level of confidence. The calculated F-statistic value of 184.693 is greater than the tabulated $\mathrm{F}$ statistic value of 3.41 which indicates that the model of the study is well fitted.

Table 6

Coefficients $^{\mathrm{a}}$

\begin{tabular}{|c|c|c|c|c|c|c|}
\hline \multirow{2}{*}{\multicolumn{2}{|c|}{ Model }} & \multicolumn{2}{|c|}{$\begin{array}{l}\text { Unstandardized } \\
\text { Coefficients }\end{array}$} & \multirow{2}{*}{$\begin{array}{c}\text { Standardized } \\
\text { Coefficients } \\
\text { Beta }\end{array}$} & \multirow[t]{2}{*}{$\mathrm{t}$} & \multirow[t]{2}{*}{ Sig. } \\
\hline & & B & Std. Error & & & \\
\hline & (Constant) & 6.275 & .148 & & 42.369 & .000 \\
\hline & ComMgt & 1.284 & .094 & .679 & 13.590 & .000 \\
\hline
\end{tabular}

a. Dependent Variable: EmCom

The estimated equation of the hypothesis is expressed as EmCom $=\beta_{0}+$ $\beta_{1}$ ComMgt $+\varepsilon$

As shown in table 6, employee commitment (EmCom) equal to 6.275 when all other variables are held constant. However, employee commitment would increase by 1.284 when there is a unit increase in compensation management (ComMgt), while other variables remain constant. As depicted in the table, the standardized beta coefficient in respect to compensation management (ComMgt) was 0.679 with T-value of 13.590 at $0.05 \%$ level of significant. This signifies that compensation management (ComMgt) is a positive predictor of employee commitment (EmCom).

Therefore, the summary of the regression analysis results indicate that the calculated p-values is less than the critical/tabulated $p$-values of 0.05 , hence, the hypothesis is rejected, while alternative hypothesis which established that compensation management has significant effect on employee' commitment among the staff of KW-IRS is adopted. Therefore, compensation management positively and significantly influence on employee' commitment among the staff. This finding corroborates the results of Koitalek (2016), which established that the compensation policies have significant and positively impact on employees' commitment in the Kenyan's Teacher Service Commission.

\section{CONCLUSION AND RECOMMENDATIONS}

Following the outcomes of the research, it could be inferred that fair compensation management is required for improved employees' commitment towards overall organizational performance and improved workplace management. It can therefore be concluded that organization that effectively and efficiently manage its compensation policy, in respect to employee's work commitment, will outperforms those that do not. 
In view of the findings reported in the study, the following recommendation should be considered towards enhancing employee work commitment:

i. The management of KW-IRS, Ilorin should endeavour as a matter of urgency put in place effective compensation policies that emphasizes on adequate compensation towards improving the welfare of its staff, with a view of treating them as the most precious and treasured assets of the organization.

ii. The compensation policies should place priority attention on the provision of overall benefits to the employees in accordance with the expectations of the employees. This is to enable them maximize better work conditions so to be more focus on the achievement of workplace's goals and objectives.

iii. Additionally, the compensation schemes of the organization should be more centered on performance enhancement considerations in respect to employees' commitment and should equally be the types that will serve as exceptional motivator for the employees to be more productive.

\section{REFERENCES}

Anthony, D. \& Govindarajan, R. (2001). Management Control System, Jakarta: SalembaEmpat.

\section{IMPLICATION OF THE STUDY}

In view of the findings of the study, this research has implications that could be beneficial to policy makers in Kwara state internal revenue service. One of which is the knowledge of the fact that fairly compensated employees in the workplace are usually more committed and eager to improve their performance on the assigned tasks, thus becoming more dedicated and devoted to the organization. However, proper attention on the part of the KW-IRS's management to the employees' contributions to the organization's success and adequate compensation to the deserving workforces are impetus for more work commitment for the affected employees.

This study is centered on a government's agency. Therefore it is essential to conduct related researches in other areas like service sectors with a view to compare the findings. This study involves only compensation management and employee's work commitment, while other variables like role conflict, role ambiguity believed to be linked to work commitment can be researched on in future.

Armstrong, M. (2007).A handbook of Human Resource Management Practice. (11th ed.) Philadelphia: Kopan Page Limited. 
Emmanuel Olaniyi, Dunmade ${ }^{1}$, Emmanuel Adewale, Adeyemi ${ }^{2}$, Ismaila Bolarinwa, Kadiri ${ }^{3}$, Modupe Olayinka, Ajayi $^{4}$ Compensation Management and Employee's Work Commitment in the Kwara State Internal Revenue Service, Ilorin, Nigeria

Attewell, P. \& Rule, J. (1991). Research and Research Methods. New York: Routledge Groups

Bari, N., Arif, U., \& Shoaib, A. (2013). Impact of non-financial rewards on employee attitude and performance in the workplace. A case study of business institutes of Karachi. International Journal of Scientific \& Engineering Research, 4(7), 2554 - 2559.

Bradford, S. \& Cullen, F.(2012). Research and Research Methods for Youth Practitioners. London: Taylor \& Francis Publishers.

Chhy, S (2019). Compensation management practices: A case study of selected private secondary schools in Phnom Penh, Cambodia. International Journal of Education and Research,7 (6), 323 -334.

Culpepper, R, Gamble, J \&Blubaugh, M. (2004). Employee stock ownership plans and three component commitment. Journal of Occupational and Organizational Psychology, 77 (2), 155-170.

Daniel, C. O. (2019). Compensation management and its impact on organizational commitment. International Journal of Contemporary Applied Researches, 6 (2), 26 - 36.

DeNissi, A.S.\& Griffin, R.W (2001). Human Resource Management. New York: Houghton Mifflin.

Dixit, V. \& Bhati, M. (2012).A Study about Employee Commitment and its impact on Sustained Productivity in Indian AutoComponent Industry. European Journal of Business and Social Sciences, 1(6), 34 - 51.

Dunmade, E.O, Kadiri, I. B., Aun, I.I, Bello, M. L \& Yahaya, I. J. (2019).Effect of human resource management practices on employees' commitment in ensuring sustainable performance in the Nigerian Security and Civil Defence Corps, Ilorin. Journal of Sustainable Development in Africa, Clarion University of Pennsylvania, 21 (4), 16 - 27.

Hansen, P \&Serin, G (2010). The European ICT clusters - an overview of selected ICT clusters in Europe $\left(1^{\text {st }}\right.$ ed. $)$ Wallin\&DalholmBoktryckeri $A B$, Lund.

Hill, H, Birley, G. \& McDougall, E.(2003). Research methods and statistics in psychology, ( $3^{\text {rd }}$ edition).

London: Hoder and Stoughton Limited

Ira, B.H (2010). Analyzing Commitment and their Influence: A Case study of TSC. University of Nairobi, MBA Unpublished Thesis.

Kandula, S. R. (2004). Employee Involvement and Empowerment for Business Results: A Study of Power Grid, Indian Journal of Industrial Relations, 39 (4), 520-529. 
Khudhair, F.S, Rahman, R. A \& Adnan, A. A.(2020). The relationship between compensation strategy and employee performance among academic staff in Iraqi universities: International Journal of Academic Research in Business and Social Sciences, 10 (1), 251-263.

Koitalek, J. N. (2016). Influence of compensation policy on employee commitment at teachers service commission in Kenya. A research project submitted to the School of Business, University of Nairobi, Kenya for the award of Degree of Masters in Business Administration.

Larbi, T. A. (2014). Effect of compensation management on employee's performance at the St. Michael's Catholic hospital, Pramso. A thesis submitted to the Department of Managerial Science, Kwame Nkrumah University of Science and Technology (KNUST), Ghana in partial fulfillment of the requirements for the degree of Master of Business Administration.

Meyer, J. P. \&Herscovith, L. (2001).Commitment in the workplace towards a general Model. Human Resource Management Review, 299-236. Meyer, J. P., Becker, \& Van Dick, R. (2006) Social identities and commitment at work toward an integrative model', Journal of Organizational Behaviour. 27 (1), 665-683.

Meyer, J. P. \& Allen, N. J (2007).Commitment in the Workplace. Thousand Oaks, C.A Sage. Muhammad, N, Andi, S, Muhtar, S \&Hanifah, E.(2018).Effect of compensation and organization culture on the motivation and commitment of coal company in the East Kalimantan province. International Journal of Scientific \& Technological Research.7 (9), 11 - 14.

Nnorom, G. K, Akpa, V.O, Egwuonwu, T. K, Akintaro, A. A, Shonubi, A.O \&Herbertson A.E (2016).The effect of compensation administration on employee's productivity. Arabian Journal of Business and Management Review (OMAN Chapter), 5 (8), 40 47.

Onuorah, A. N, Okeke, M.N., \& Ibekwe, A. I. (2019).Compensation management and employees' performance in Nigeria. International Journal of Academic Research in Business and Social Sciences 9 (2), 384 - 398

Osibanjo, O. A, Abiodun, A. J., \& Fadugba, A. O. (2012) Executives Perception of the Impact of Flexitime on Organisational Performance: Evidence from the Nigerian Private Sector: International 


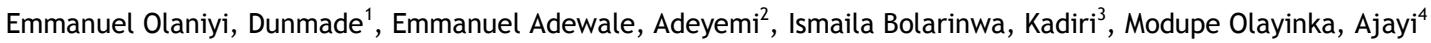
Compensation Management and Employee's Work Commitment in the Kwara State Internal Revenue Service, Ilorin, Nigeria

Journal of Applied Behavioral Economics (IJABE). 1 (3).

Osibanjo, O. A, Adeniji, A. A, Falola, H.O. \& Heirsmac, P. T.(2014).Compensation packages: a strategic tool for employees' performance and retention. Leonardo Journal of Sciences, 25, 65-84

Prayoga, S. D \& Achmad, S. S. (2017).Effect of compensation on satisfaction and employee performance.Management and Economics Journal (MECJ), 1(1),89-78.

Saharuddin, D. N, Abdul, R. $M$, Baharuddin, L \& Budiandriani, A. (2020). Organizational culture, work commitment and compensation effect on job satisfaction and police members' performance in Makassar metropolitan city police (POLRESTABES). EJBMR, European Journal of Business and Management Research, 5 (2), 1 - 6.

Suleiman, O, Ochidi, Z, Akinroluyo, B. I. \& Olumoyegun, P. M.(2018). Effect of direct and indirect compensation on employees' job satisfaction of selected microfinance banks in Ilorin metropolis Journal of Good Governance and Sustainable Development in Africa (JGGSDA), 4, (2), 115 - 130.

Torrington, D, Hall, L \& Taylor, S., (2005). Human Resource Management. (6th ed). Prentice Hall, Spain.
Vroom, V. H. (1964). Work and Motivation. New York: John Wiley, Wiley. 